Косьмин А.Д. ${ }^{1}$, Кузнецов В.В. ${ }^{1,2}$, Кузнецова О.П. ${ }^{1}$, Гальцева О.В. ${ }^{2}$

${ }^{1}$ Омский государственный технический университет

${ }^{2}$ Национальный исследовательский Томский политехнический университет

\title{
Проблемы повышения эффективности инвестиций в образование
}

\begin{abstract}
АННОТАЦИЯ:
Определяются масштабы и эффективность инвестиций в образование, научные исследования и разработки. Обосновывается необходимость изменения социального статуса системы образования и увеличения масштабов финансирования как необходимого условия повышения качества подготовки специалистов.

КЛЮЧЕВЫЕ СЛОВА: формальное и реальное образование, качество образования, эффективность инвестиций в образование и научные исследования, приоритеты, мотивация
\end{abstract}

JEL: $E 22,123,128$

ДЛЯ ЦИТИРОВАНИЯ:

Косьмин А.Д., Кузнецов В.В., Кузнецова О.П., Гальцева О.В. Проблемы повышения эффективности инвестиций в образование // Креативная экономика. -2016 . - Т. 10. № 7. - С. 793-812. — doi: 10.18334/ce.10.7.35396

Косьмин Анатолий Данилович, доктор экономических наук, профессор, Омский государственный технический университет (Kosmin.39@mail.ru)

Кузнецов Владимир Владимирович, кандидат технических наук, доцент, Омский государственный технический университет; младший научный сотрудник, Национальный исследовательский Томский политехнический университет

Кузнецова Ольга Павловна, доктор экономических наук, профессор, Омский государственный технический университет

Гальцева Ольга Валерьевна, кандидат технических наук, доцент, Национальный исследовательский Томский политехнический университет

ПОСТУПИЛО В РЕДАКЦИЮ: 07.06.2016 / ОПУБЛИКОВАНО: 30.07.2016

ОтКРЫтЫЙ ДОСТУп: http://dx.doi.org/10.18334/ce.10.7.35396

(с) Косьмин А.Д., Кузнецов В.В., Кузнецова О.П., Гальцева О.В. /

Публикация: ООО Издательство "Креативная экономика"

Статья распространяется по лицензии Creative Commons CC BY-NC-ND

(http://creativecommons.org/licenses/by-nc-nd/3.0/)

ЯЗЫК ПУБЛИКАЦИИ: русский 


\section{Введение}

В современном мире главной силой, определяющей его цивилизованное, прогрессивное развитие, являются люди новых способностей, разумных амбиций, высокого интеллекта, стереоскопического мышления, сильной мотивации к накоплению и обновлению своих знаний и компетенций (как возможностей эффективного поведения в определенных жизненных ситуациях и в профессиональной деятельности), высокого духовного и моральнонравственного потенциала (как особей формы общественного сознания и вида общественных отношений).

Эти люди, столь необходимые в современном мире, - это более современный, высококачественный продукт сферы образования, непременно долженствующей быть также современным и высококачественным как по объективным, так и по субъективным критериям и показателям.

Мировой опыт свидетельствует, что социально-экономическому прорыву, прежде всего экономическому взлету, предшествуют солидные инвестиции государства в образование, материализующиеся не столько в масштабах «охвата» образованием, сколько в качестве, продуктивности подготавливаемой рабочей силы, соответствующей рынку труда, потребностям различных сфер человеческой деятельности.

Таблицы 1 и 2 свидетельствуют о том, что все страны, добившиеся и добивающиеся успехов в своем социально-экономическом развитии, осуществляли и осуществляют широкомасштабные инвестиционные программы развития системы образования и научных исследований.

В таблице 1 приводится уровень удовлетворенности качеством образования в ведущих странах мира, среди которых Россия занимает последнее место наряду с Суданом и Гаити (после России - Сенегал, Мали, Мавритания и Гвинея).

Население России по формальным признакам одно из самых образованных в мире: по доле населения с третичным образованием Россия опережает все страны, а по доле населения с высшим образованием уступает только десяти наиболее развитым странам. Однако высокий уровень образования населения дает в России меньший эффект, чем в других странах: учитывая уровень образования российского населения и в соответствии со сложившимися в мире соотношениями душевой ВВП, в России должен был быть в два раза выше фактического. Этого не может 
случиться главным образом потому, что качество российского образования не соответствует требованиям современной экономики и общества.

Если раньше приоритетом образовательной политики стран мира был вопрос доступа населения к образованию (заметим, что закон о школьном обязательном для всех образовании был принят впервые в Швеции в 1842 году, через полвека в Англии, в России намного позже - во второй половине 20 века) как ко всеобщему гарантированному (бесплатному) благу, то в последние годы пришло понимание того ставшего уже очевидным факта, что в образовательной политике приоритетом становится вопрос качества образования, его соответствие по структуре и содержанию потребностям экономики страны. Мировая статистика выявила положительную корреляцию между качеством образования и его продолжительностью (имея в виду продолжение обучения в процессе производства) и экономическим развитием.

Удовлетворенность качеством образования - это процент респондентов, ответивших «удовлетворен/удовлетворена» на вопрос Всемирного опроса Гэллапа: «удовлетворены ли вы системой образования, или вы ею не удовлетворены?»

Субъективная оценка качества образования является надежным и необходимым дополнением объективной оценки, выражаемой показателями результативности (эффективности) применения, использования полученных знаний в практической деятельности акторов.

Удовлетворенность качеством образования есть относительное удовлетворение потребностей, связанных с образовательным процессом. Но так как потребности осознаются людьми в форме интересов, то, следовательно, удовлетворенность - это состояние реализации соответствующих интересов и одновременно отражение связи между личностью человека и архитектурой образовательной сферы. Поэтому состояние удовлетворенности качеством образования оценивается не безотносительно, а в сопоставлении с определенными общественно значимыми потребностями различных сфер трудовой деятельности. Очень низкий показатель качества образования в России - это показатель того, что уровень потребностей и интересов у обучающихся намного выше тех возможностей, которыми обладают образовательные учреждения. Удовлетворенность качеством образования - это не только результат воздействия «сферы обучения», но и производное от уровня притязаний обучающихся (и плохо учат, и плохо учатся). 
В таблице 1 приведены данные невысоких результатов российских школьников в международном обследовании качества образования PISA (Programme for International Student Assessment) - международной программы по оценки образовательных достижений учащихся (оценивается грамотность в области математики, чтения и естествознания 15-16-летних учащихся). По уровню учебных достижений результаты размещаются на шести уровнях, самый высокий - шестой).

В первом тестировании PISA-2000 из 31-ой страны Россия заняла 25-е место в рейтинге по результатам успешности обучения, в 2003 - 29-е место из 37, в 2006 - 37-е место из 58, в 2009 - 40-е место из 44 и в 2012 - 39 из 65. Высокие ранговые места занимают Гонконг, Сингапур, Республика Корея, Япония, Финляндия.

Россия «уверенно» теряет ранговые места учеников страны: по чтению с 27 места в 2000 году опустилось до 43-го в 2012 году, по математике соответственно с 22-го до 38-ого места, и по естественнонаучным предметам с 27- го до 39-ого места [11].

Следовало бы результаты этого международного обследования дополнить собственными с целью: а) определения уровня дифференщиации результатов обучения по различным школам (городским и сельским); б) выявления наиболее результативньх школ; в) распространения, использования опыта наиболее результативньх школ.

Качество общеобразовательной подготовки, уровень которой запредельно недостаточен для усвоения новых профессиональных знаний, умений и навыков, адекватных требованием информационной экономики, обусловливает дефицит современньх кадров как фактора, ограничивающего экономический рост. Дефицит кадров в значительной мере обусловлен несоответствием структуры и масштабов профессиональной подготовки кадров современным запросам экономики. Профессиональные учебные заведения начали открывать набор на те специальности, которые пользуются спросом у молодежи. В массовом масштабе далекие по своему профилю от подготовки экономистов, бухгалтеров, юристов, менеджеров учебные заведения осуществляют обучение по указанным специальностям. В условиях грандиозной коммерциализации высшего и среднеспециального образования этот процесс набирает обороты, но никак не базируется на информации о реальной и перспективной потребности в кадрах, поскольку упразднены традиционные способы взаимодействия «система образования производство». 


\begin{tabular}{|c|c|c|c|c|c|c|c|c|c|c|c|c|c|c|c|}
\hline \multicolumn{2}{|c|}{ 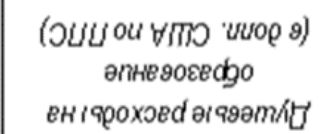 } & $\%$ & ำ & 웜 & স্ন্তি & ষ্ঠে & $\frac{\bar{\sigma}}{\mathrm{N}}$ & প్ల్ & & & 守 & 赵 & $\sqrt[5]{\frac{5}{2}}$ & & হ్ల \\
\hline 芠 & 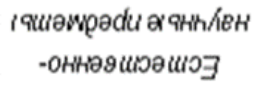 & $\frac{\pi}{4}$ & గ్ర & ষ্ণ & జ్రి & क़ & ஓ্ণ & ज्ञ & $\mathscr{g}$ & 号 & कुष & గొ & 串 & $\%$ & \\
\hline 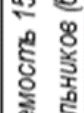 & әniнüh & স্ণ & 电 & পి & జ్ల్ర & 多 & 曲 & ஜ్రి & 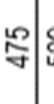 & ס্口ে & క్రి & 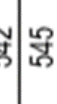 & \% & \% & \\
\hline 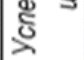 & exnuewa & 导 & 吾 & $\mid$\begin{tabular}{l}
$\mathscr{2}$ \\
\hdashline \\
$q$
\end{tabular} & $\infty$ & হ্ & |ֶু & ஜ్గి & & & 守| & $\overline{5}$ & 芯 & 守 & \\
\hline
\end{tabular}



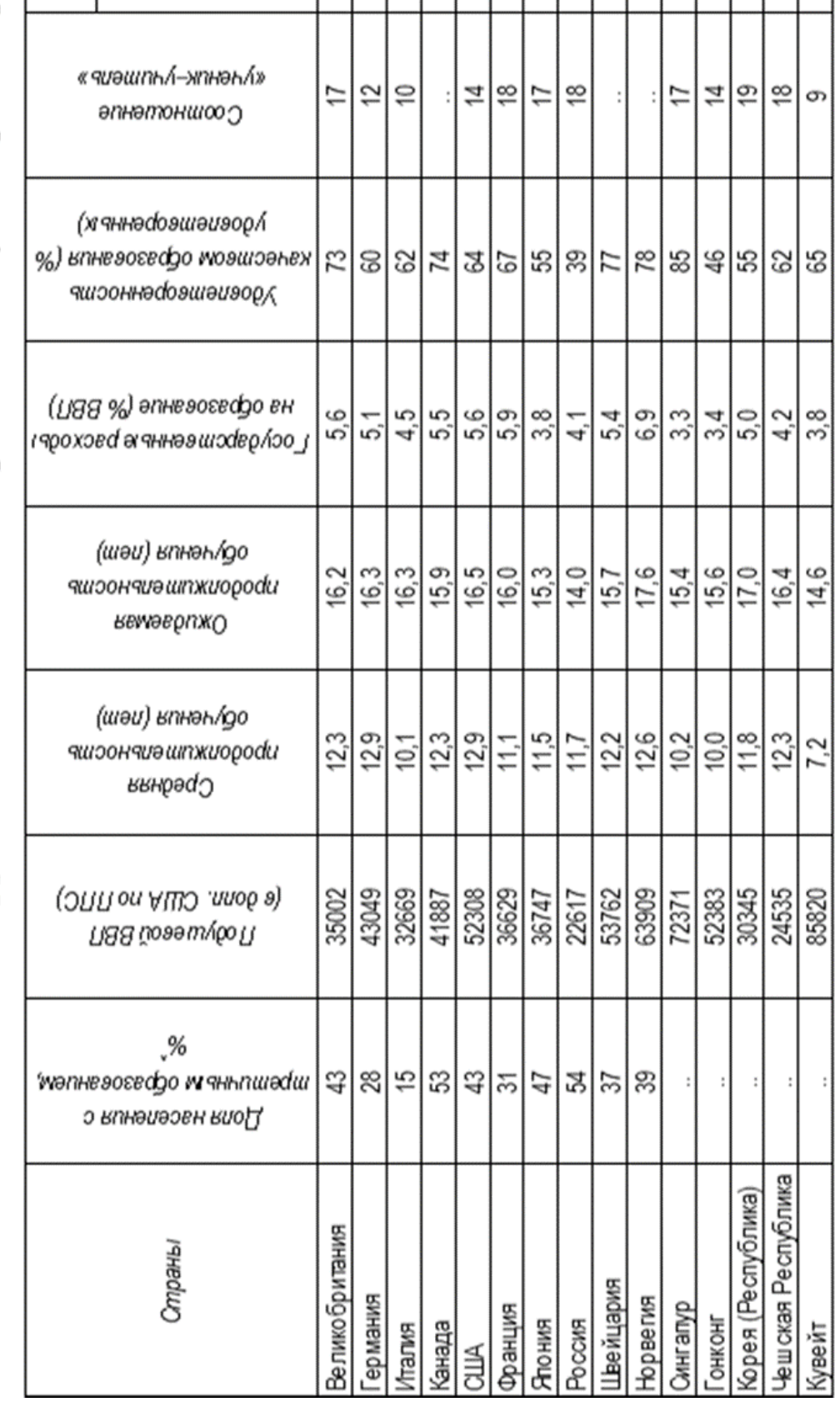


Поэтому идет неконтролируемый процесс подготовки кадров, спрос на которые общество не заявляло (и, стало быть, не инвестировало). Общество нуждается в тех специалистах, в которых ощущается их дефицит, поэтому необходимо повысить спрос на эти специальности со стороны частных лиц - выпускников общеобразовательных школ.

Речь идет о специалистах со средним профессиональным образованием, на расширение «номенклатуры» которых особое внимание обратил Президент Путин В.В. в своем ежегодном Послании Федеральному Собранию 3 декабря 2015 года [12].

Что же касается высшего образования, то, по нашему глубокому убеждению, государство должно изменить свое отношение к нему, которое по всем имеющимся признакам является фактом, констатирующим всеобщее высшее образование, но не имеющим институциональной природы. Речь идет не только о повышении (взлетах) государственных обязательств в сфере высшего образования (в части подготовки по заявкам руководителей крупнейших государственных корпораций, государственных служб и ведомств и других, «мериторных» ${ }^{1}$ специалистов), но прежде всего о достижении максимальной эффективности инвестиций в образование.

В области образования и научных исследований примером для подражания следует полагать Республику Корею, которая активно инвестировала в образование с момента получения независимости в конце 1940-х гг. и продолжала расширять доступ к обучению во времена политических неурядиц и войн. В итоге Республике понадобилось примерно пять десятилетий, чтобы добиться почти всеобщего начального, затем среднего и высшего образования [2, с. 87]. Стремительно развивающаяся страна превосходит Россию по душевным расходам на образование в 1,6 раза, а на научные исследования и разработки - в 3,5 раза. А более высокое качество образования материализуется в изобретениях и открытиях, по количеству превышающих российские в 7 раз, с удельными затратами вдвое меньшими российских. Производительность труда корейского научного работника в четыре раза выше российского (табл. 1, 2).

\footnotetext{
${ }^{1}$ Мериторные блага (товары и услуги) - это блага, спрос на которые со стороны частных лиц отстает от желаемого обществом, которые по решению общества должны гарантироваться людям независимо от их платежеспособности и которые необходимы для обеспечения социальной стабильности общества.
} 
Таблица 2

Эффективность инвестиций в научные исследования и разработки

в ведущих странах мира

\begin{tabular}{|c|c|c|c|c|c|c|c|}
\hline Страны & 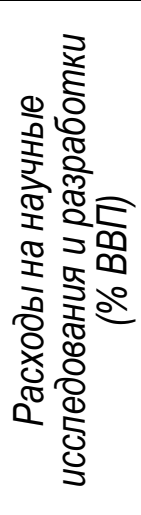 & 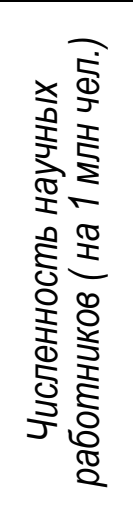 & 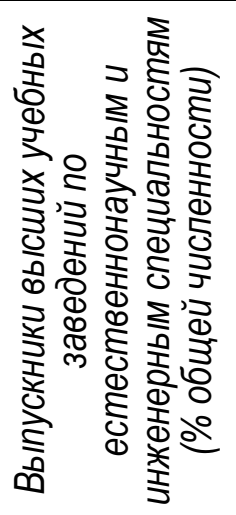 & 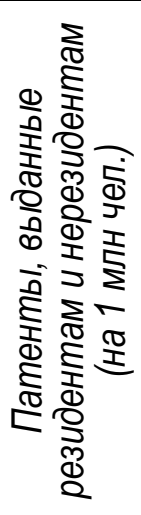 & 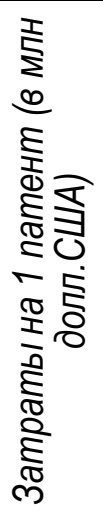 & 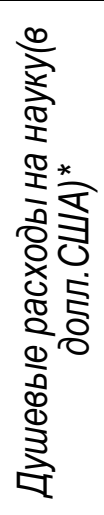 & 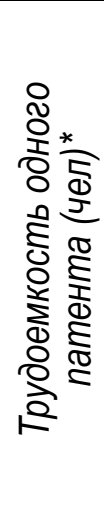 \\
\hline Великобритания & 1,8 & 3794,2 & 21,7 & 90,2 & 6,9 & 630 & 42 \\
\hline Германия & 2,8 & 3780,1 & 28,6 & 166,2 & 6,8 & 1205 & 23 \\
\hline Италия & 1,3 & 1690,0 & 20,5 & 303,4 & 1,4 & 425 & 5 \\
\hline Канада & 2,0 & 4334,7 & 21,1 & 562,1 & 1,4 & 838 & 8 \\
\hline США & 2,8 & 4673,2 & 15,5 & 707,6 & 1,9 & 1465 & 7 \\
\hline Франция & 2,2 & 3689,8 & 26,2 & 157,7 & 5,1 & 806 & 23 \\
\hline Япония & 3,4 & 5183,3 & 20,6 & 1759,9 & 0,7 & 1249 & 3 \\
\hline Россия & 1,3 & 3091,4 & 28,1 & 212,1 & 1,4 & 294 & 14 \\
\hline Швейцария & 3,0 & 3319,8 & 21,6 & 96,7 & 15,7 & 1613 & 34 \\
\hline Норвегия & 1,8 & 5503,7 & 15,3 & 334,0 & 3,4 & 1150 & 16 \\
\hline Сингапур & 2,7 & 5834,0 & & 873,3 & 2,1 & 1954 & 6 \\
\hline ГОНКОНГ & 0,8 & 2759,5 & 34,7 & 758,9 & 0,5 & 419 & 4 \\
\hline $\begin{array}{l}\text { Корея } \\
\text { Республика }\end{array}$ & 3,4 & 4946,9 & 31,5 & 1428,8 & 0,7 & 1031 & 3 \\
\hline $\begin{array}{l}\text { Чешская } \\
\text { Республика }\end{array}$ & 1,5 & 2754,8 & 23,8 & 86,8 & 4,8 & 368 & 32 \\
\hline
\end{tabular}

${ }^{*}$ Рассчитано авторами

Источник: [2,с.186;3,с.196]

Особо подчеркнем, что в сфере подготовки кадров, в индустрии образования как нигде очень явственно (в чистом виде) проявляются два фундаментальных экономических закона: закон Г. Госсена (закон уменьшающейся предельной полезности) и закон уменьшающейся предельной эффективности. В первом из них утверждается, что по мере роста некоего блага его предельная полезность (ценность) уменьшается. Во втором законе - что по мере роста некоего производственного ресурса предельная отдача (производительность) от него падает.

Огромная масса невостребованных образовательных «корочек»суть свидетельство утраты их ценности и ценности обладателей этих корочек (проявление закона Госсена). А отдача внешняя (приращение ВВП по вектору образования) и внутренняя (приращение доходов 
работающих по этому же вектору) от инвестиций в образование падает (проявление закона уменьшающейся предельной эффективности).

Вывод: учить надо всех (учат же своих детей староверыотшельники в объеме 5-летней программы средней школы), но в строгом соответствии со здравым смыслом, следуя Адаму Смиту. Речь идет о том, что для того, чтобы достичь максимальной эффективности инвестиций в образовании, следует использовать модельный подход, позволяющий представить сферу образования, индустрию знаний как имеющую не только два потенциальных бинарных исхода: учить - не учить, всех или немногих, непрерывно или дискретно и т.д. Бинарный подход к этой сфере в принципе неприменим. Еще раз повторим, что учиться можно и нужно всем, необходимо только знать образовательным властям: когда (экономическая динамика), зачем (для кого) и сколько (количество лет обучении).

Итак, учить нужно всех, но до порога, достаточного и необходимого для сохранения генофонда нации и повышения ее общей культуры. Но поскольку у каждого имеется свой интеллектуальный порог, то, стало быть, принцип «равенства возможностей», сконструированный идеологами советской власти, должен быть отвергнут.

В этой связи небезынтересно напомнить о том, что консервативное правительство Великобритании (исправляя ошибки столетней давности) отвергло упомянутый выше принцип «равенства возможностей» еще в 1979 году, введя взамен принцип элитарности и трактуя образование как «великое сито», позволяющее осуществлять интеллектуальный и социальный отбор. Их политика и взяла на вооружение тезис о необходимости повышения стандартов и качества образования, обосновывая это тем, что только часть населения обладает необходимыми для обучения способностями. Правительство вынесло вердикт, что «больше означает хуже», а следовательно, увеличение числа студентов наносит ущерб качеству подготовки.

Таким образом, адекватные времена, английские образовательные стандарты и возросшие требования к качеству образования «отсекают» ту часть выпускников, интеллектуальный порог которых или способности для обучения которых явно недостаточны. И следовательно, инвестиции становятся избирательными, ориентированными главным образом на людей, обладающих природными креативными способностями и особым социальным качеством - обучаемостью. И это оправдано, поскольку из 
фантастического многообразия людей целесообразно отбирать «особые личности», сущность которых, по Марксу, «составляет не ее борода, не ее кровь, не ее абстрактная физическая природа, а ее социальное качество» [6, c. 242].

Идея англичан получила планетарное признание, кроме России (у самих англичан только 60\% выпускников средних школ способны обучаться в вузе, в Италии - 63\%, в Польше - 59\%, в Чешской Республике - 37\%, во Франции - 56\%, в Израиле - 57\%, в США 63\%) [5].

Логическим продолжением реализации правила жесткого, но справедливого отбора абитуриентов в вузы должна стать такая же жесткая и такая же справедливая аттестация обучающих (профессорскопреподавательского состава), практически «поголовно» остепененных, но не по критерию научно-педагогической зрелости, а по критерию объективно обусловленной необходимости поддержания их более или менее сносного уровня жизни (диссертации российских преподавателей справедливо уподобить пространным заявлением с просьбой об увеличении заработной платы).

В результате реализации отмечаемого проекта возрастает вероятность достижения оптимального соотношения обучаемых и обучающих с одновременным повышением качества подготовки первых и улучшением материально-креативного благосостояния вторых.

Что же касается менее способных, но платежеспособных и желающих получить высшее образование (являющееся по факту формальным), то их «душевный порыв» заслуживает одобрения хотя бы потому, что они стремятся к повышению образованности, $\mathrm{K}$ минимизации «бездонного человеческого невежества» (Фейербах). Более того, осуществляя свой интерес, они тем самым осуществляют еще нечто более значительное - сохранение генофонда, умножение интеллектуального потенциала страны («образованность народа есть одна из величайших его сил» - Д.И. Пихно.)

Для большей части платежеспособной молодежи более значимыми оказываются инструментальные ценности (средство для достижения других целей, обязательство перед родителями или просто диплом), в отличие от терминальных - познания и раскрытия способностей (полагая, что способности неизменны, что является большой ошибкой). 
Различные способности, как познавательные, так и когнитивные, постоянно развиваются в разных учебных ситуациях, что способствует дальнейшему обучению (обучению на производстве в течение всей трудовой жизни) и эффективному труду. Мотивация к учебе не только повышает результаты образования, но также «отсекает» девиантные формы поведения (употребление психоактивных средств, алкоголя и др.), коррелирующие с преступностью.

Замотивировать молодежь на терминальные ценности вполне представляется возможным, если постараться повысить уровень и качество взаимного общения в студенческой аудитории, долженствующего «запустить» процесс развития взаимообусловленных познавательных, социальных, эмоциональных и языковых способностей ${ }^{2}$. Однако результативность этого диалога зависит от подготовленности и активности обеих сторон этого процесса преподавателя и студента, и только в этом случае трудный процесс обучения будет обретать признаки наслаждения (Эзоп) ${ }^{3}$.

А. Смит одним из первых показал выгоды общественного разделения труда, имея в виду, прежде всего, извлечение пользы из различий тех способностей, которыми природа наделила различных людей. «От природы между философом и грузчиком, - пишет Смит, различие и в половину не столь велико - в смысле дарований ума, - как различие между дворняжкой и борзой...» [8, с. 33], которые никакой пользы друг другу не приносят в отличие от философа и грузчика, оказывающихся весьма полезными друг другу.

Позволим и мы себе интеллектуальное допущение о не столь великом различии между преподавателем (профессором, доцентом, молодым ассистентом) и студентом, способным к постоянному саморазвитию. Именно это обстоятельство по определению мотивирует взаимное разумное (принцип развития - притяжение страстей) стремление обеих сторон к достижению удовольствия и наслаждения от совместного «образовательного» труда.

Ведущая роль в этом взаимодействии принадлежит учителю, долженствующему быть интересным, привлекательным для своих учеников, не только и не столько по критерию глубокого знания своего предмета (философии предмета), сколько по уровню культуры (речи,

\footnotetext{
2 «Покуда человек не говорит, неведом дар его, порок сокрыт» - Саади.

${ }^{3}$ Немирович-Данченко в диалоге с А. Чеховым сетовал по поводу неподготовленности театралов к пониманию, адекватному восприятию театрализованного Гоголя: то ли народ поднимать до уровня Гоголя, то ли Гоголя опускать до уровня народа.
} 
обращению, манеры поведения и т.д.), широты своего кругозора, хорошо знающего классиков, различные научные парадигмы (классиков литературы - неявных философов) не из «вторых рук», нередко их искажающих, а из их произведений (сочинений). Учитель должен не только освежать в своей памяти эти знания с помощью учеников, выполняющих домашнее задание, хорошо выверенным злободневным проблемам, но и в процессе их обсуждения «размещать» в головах учеников то, что им в голову никогда бы не пришло - методологию познания перманентно изменяющейся действительности.

Следует отметить, что в целом в российском обществе наблюдаются двойственное отношение к индустрии знаний. С одной стороны, при высокой ценности высшего образования в обществе отношение к нему у сегодняшних россиян, как уже отмечалось, преимущественно утилитарное: хорошее образование ценится в первую очередь как необходимое условие повышения социального статуса, карьерного роста и роста материального благосостояния. С другой стороны, огромная масса подготовленных, но невостребованных «образованцев» (А. Солженицын), обладателей различных образовательных корочек, - суть свидетельство утраты их ценностей и ценностей обладателей этих корочек.

Несоответствие профессиональной подготовки кадров (структуры и масштабов) современным запросам экономики, помноженное на запредельно недостаточный уровень их качественной подготовки, и обусловливает дефицит адекватных требованиям совершенной экономики кадров как фактора, ограничивающего экономический рост. Высокое качество профессиональной подготовки следует рассматривать как функцию взаимодействующих и дополняющих друг друга аргументов - высокого профессионализма учителей и способных, заинтересованных в получении реального (а не формального) высшего образования учеников. Существенные подвижки в качестве подготовки специалистов всех уровней, следовательно, зависят, во-первых, от создания тех условий (зарплата, дополнительные и существенные преференции за высокие результаты научно-педагогической деятельности и проч.), при которых представителям интеллектуальных профессий, обеспечивающих производство, сохранение, распространение и прирост знаний у учеников, были бы высоко замотивированы на непростые реальные усилия, направленные на то, чтобы у пришедших на «поля знаний» сформировать определенную 
склонность к потреблению ${ }^{4}$ и закреплению необходимых знаний; вовторых, эффективность образовательного процесса зависит от желания 5 , терпения, усердия и адаптивных способностей учеников, достаточных для знакомства и усвоения всего того «немногого» ${ }^{6}$, что облегчит приобретение многого из того, что необходимо человеку для долгой и счастливой жизни.

Кто и как учит специалистов ${ }^{7}$ (долженствующих быть высококачественными, с высоким потенциалом компетентности и креативности), мы уже отмечали [4, с. 50]. Выявляемое авторами всеобее непонимание (незнание) дисциплин федеральной компоненты, например, является следствием не всеобщей бестолковости студентов, а скорее всего, неясности у самого преподавателя (в результате чего вуз рискует потерять имиджевую привлекательность со стороны, прежде всего, желающих получить не формальное, а реальное качественное образование, соответствующее запросам рынка труда), волей-неволей читающего курс лекций по дисциплине, далеко отстоящей от его профессиональной подготовки, в результате чего обучение в вузе «озадачивает неприятным образом» (Гончаров). Подобная ситуация была предвосхищена великим русским баснописцем И. Крыловым: «Беда, коль пироги начнет печи сапожник, А сапоги тачать пирожник».

Каждая учебная дисциплина должна быть жестко персонифицирована, а их «меню», набор - определяться исключительно и безоговорочно кадровым потенциалом кафедры, ее учеными, имеющими не только соответствующие учебники или учебные пособия, но и - что самое главное - серьезные научные публикации, все вместе составляющие эскорт сопровождения этих специалистов, зачастую оказывающихся рядом с «великими» завкафедрами, которые не могут терпеть рядом с собой великих, и вынужденных рассудительно, мирно (без сопротивления) облегчать им жизнь, заключая соглашения с менее великими администраторами, но более разумными и нуждающимися в высококлассных специалистах (и не страдающими врожденным эготизмом).

\footnotetext{
4 «Мало привести лошадей к водопою, нужно, чтобы они хотели пить» - Поговорка.

5 «Ученик, который учится без желания, - это птица без крыльев» - Саади.

${ }^{6}$ «Если вы приобрели немногое, это зачастую легко будет приобрести многое, но трудность состоит в том, чтобы приобрести немногое»-А. Смит.

${ }^{7}$ «Не так важно, чему учат в школе, а важно, как учат»- Макс Планк.
} 
В данном месте следовало бы обратиться к комментариям Энгельса, одного из положений Гегеля: «Ни одно из философских положений, - отмечал $\Phi$. Энгельс, - не было предметом такой привлекательности со стороны близоруких правительств и такого гнева со стороны не менее близоруких либералов, как знаменитое положение Гегеля: все действительное разумно; все разумное действительно. Ведь оно, очевидно, было оправданием всего существующего, философским благословением деспотизма, полицейского государства, королевской юстиции, цензуры. Так думал Фридрих-Вильгельм III; так думали и его подданные. Но у Гегеля вовсе не все, что существует, является безоговорочно также и действительным. Атрибут действительного принадлежит у него лишь тому, что в то же время необходимо» [10, c. 274].

Необходимо знать, различать, что на самом деле действительно и необходимо, в конечном счете оказывающееся и разумным; в обывательской жизни все действительно; но существуют различия между проявлениями, миром событий и действительностью, которая в своем развертывании раскрывается как «необходимость».

Действительное не является атрибутом, присущим данному общественному или политическому порядку при всех обстоятельствах и во все времена. «По мере развития, все, бывшее прежде действительным, утрачивает свою необходимость, свое право на существование, свою разумность, и ее место занимает новая, жизнеспособная действительность, занимает мирно, если старое достаточно рассудительно, чтобы умереть без сопротивления, - насильственно, если оно противится этой необходимости» [10, с.274-275].

Возникает вопрос: утратила ли советская система образования, признанная в 60-70-е годы прошлого столетия самой лучшей в мире (по эффективности и демократичности), обеспечивающей достаточно высокий интеллектуальный уровень населения в целом, подготавливающей высококвалифицированных специалистов для народного хозяйства и вырастившей плеяду выдающихся ученых, организаторов всемирно известных и признанных научных школ в области фундаментальных и прикладных исследований, актуальность? Если учесть, что страны, на сегодняшний день имеющие наиболее высокие показатели интеллектуального развития учащихся, активно и эффективно используют опыт советской модели образования (в Японии, например, которая использовала к тому же самое ценное в 
нереализованной в СССР концепции косыгинской экономической реформы и благодаря чему совершила «экономическое чудо»), то ответ на поставленный вопрос будет отрицательным.

Российские образовательные власти вместо постепенного и разумного, адекватного требованиям изменяющегося мира, реформирования системы образования (мало, похоже, кто помнит прорывную концепцию образования гениального Шаталова, действовавшего в своих начинаниях в строгом соответствии с третьим тезисом Маркса о Фейербахе, согласно которому «изменяющиеся люди суть продукты иных обстоятельств и измененного воспитания, и что воспитатель сам должен быть воспитан» $[9, \quad$ с. 262], и предусматривавшего необходимость осуществления прорывных действий в подготовке учителя, в повышении требований к его профессионализму и в создании условий для его высокой мотивации ${ }^{8}$ взяли на «вооружение» Болонскую систему развития образования, ядром (квинтэссенцией) которой является так называемый компетентностный подход к содержанию образования, имеющий целью подготовку специалистов, обладающих определенным уровнем компетенции для своей профессиональной деятельности. В условиях высокой динамичности современного мира этот подход, как полагают многие ученые и специалисты в области образования, оказывается совершенно несостоятельным (это понимание приходит и самим ученикам) для российского общества, имеющего уникальный менталитет народа, его национальные особенности и ценности.

России нужна своя (незаимствованная) самостоятельная открытая образовательная концепция, своя национальная образовательная политика, реализация которой позволит не только возродить (восстановить) утраченное (выплеснутого «ребенка»), разумное и действительное, но и осуществить назревший прорыв в сфере индустрии знаний. Для этого следует придать образованию статус особой сферы материального производства, производства человека, человеческого капитала, инкорпорированного в его личности, инвестиции в который должны войти в число государственных приоритетов в России, поскольку образование является одним из ключевых факторов обеспечения национальной безопасности (и в первую очередь безопасности экономической).

\footnotetext{
${ }^{8}$ Именно на это особое внимание обратил Президент В.В. Путин в своем ежегодном Послании Федеральному Собранию 3 декабря 2015 года [12].
} 
Индустрию знаний, образования нельзя опускать до уровня какого-то пособия. По Далю, «услуга - помощь, пособие или угождение. Оказать кому услугу, сделать нужное, угодное; ...услужник прислужник, служитель, слуга (служанка)» [1, с. 512].

Образование, следовательно, не есть составляющая сферы услуг (низведенная до уровня услуг ЖКХ или салонов красоты), а второй вид производства - производства и воспроизводства человека, являющегося одушевленным основным капиталом. Осознание этого факта приходится на период создания просвещенной политической экономии шотландским мудрецом А. Смитом.

Со времен А. Смита экономисты «качнулись» от неодушевленных механизмов (коим уделялось гораздо больше внимания в их усовершенствовании, чем усовершенствованию тела и духа [6, с. 220221]) к одушевленному фактору производства, к одушевленному основному капиталу - к человеку (К. Маркс, Мак-Куллох и другие), являющемуся к тому же конечным результатом общественного производства.

К. Маркс рассматривал «производство человека - потребительное производство - как второй вид общественного производства» (5, с. 27), как производство личности ${ }^{9}$, личностного потенциала и его (человека) различных форм жизнедеятельности, результаты которых (форм) потребляются производительно.

В заключение отметим, что в современных условиях доминирующая претензия работодателей и общества к профессиональным образовательным учреждениям - это их неспособность научить мыслить выпускников ${ }^{10}$, свой образовательный «продукт».

Перефразируя Бальзака, скажем, что высшее учебное заведение «порождает» больше ростков, чем деревьев», которые (ростки) - всего лишь «образованцы» (А. Солженицын), имеющие сертификаты даже высшей пробы и которые доводятся до требуемой работодателями кондиции в созданных различных учебных центрах многих компаний, оперативно отреагировавших (не одобривших) на образовательный «продукт» вуза, оказавшийся совершенно неконкурентоспособным из-за отсутствия жизненного опыта, неспособности проявлять инициативу,

\footnotetext{
${ }^{9}$ А. Маркс, как и А. Смит, рассматривал человека как результат труда, по аналогии с машинами, которые он создает.

${ }^{10}$ «Не мыслям надо учить, а мыслить» - И. Кант
} 
принимать самостоятельные решения, брать на себя ответственность, а также из-за неготовности к интенсивному и творческому труду ${ }^{11}$, к продуктивному взаимодействию со старшим поколением, добросовестным, ответственным и очень эффективным в организации работы и бизнеса.

Как известно, со времен Платона и Аристотеля развиваются два противоположных подхода к образованию, к обучению: а) как к игре Платон и б) как к труду - Аристотель. Всемирная отзывчивость русской души (Ф. Достоевский) на эти два подхода привела к пониманию относительности их противопоставления и признания их тождественности, поскольку эти два подхода являются дополняющими и развивающими друг друга и потому составляющими одно методологическое целое ${ }^{12}$.

Первичная семантика понятия «игра» - это «забава, установленная по правилам, и вещи для того служащие» ${ }^{13}$. Похоже, Аристотель под игрой и понимал главным образом забаву.

Вторичная семантика более продуктивна - «игра» - это, прежде всего, дискурс (рассуждения, умозаключения) хорошо подготовленных в результате упорного труда специалистов различных областей знаний, обучающихся и обучающих, т.е. игра не азартная, а «ровная», где входит в расчет уменье» [1, с. 7]. Игры коммерческие, биржевые, организационно-деятельностные (П. Щедровицкий) как всеобщая игровая форма результатом своим имеют некий продукт коллективной мысли, в которую конвертируются компетенции всех участников дискурса. Иначе говоря, игра, ее целесообразность и продуктивность, предполагает априорность усердного труда (существует так называемое правило 10000 часов интенсивного труда по конвертации геннозаданных способностей, таланта в успех - в спорте (Фишер - чемпион мира по шахтам), в искусстве (Моцарт), литературе, науке и проч.).

Труд же, в своей всеобщности, - это целесообразная, осмысленная деятельность человека по преобразованию окружающей действительности и самого себя (Достоевский). Труд - первое условие жизни ${ }^{14}$, обеспечивающее «изготовление служащих для игры» вещей (например, разработка сценария организационно-деятельностной игры, методологического обеспечения, подготовка игротехников, роль

\footnotetext{
${ }^{11}$ «Ученик - не сосуд, который надо наполнить, а факел, который надо зажечь» - Плутарх.

12 «Противоположности - суть начало существующего» - Аристотель.

13 «Когда играют - не учатся, а когда учатся - не играют» - Аристотель.

14 «В деяниях начало бытия» - Иоганн В. Гете.
} 
которых заключается в переключении мыслительной деятельности игроков на поиск решения проблемы, лежащей между крайними точками зрения, противоположными подходами к образованию) ${ }^{15}$.

Таким образом, игра в труд «взаимно подстрекают друг друга» (Ф. Петрарка), а их совместное, комбинированное воздействие на образование позволит достигать эффекта эмерджентности, превышающего эффекты, достигаемые (оказываемые) каждым подходом в отдельности. Диалектическое взаимодействие двух подходов к обучению является залогом приобретения указанного ранее смитианской «немного»-долженствующей мыследеятельности выпускника учебного заведения, обремененного теорией познания, «добытыми» во время обучения компетенциями, адекватными запросами общества. Синергия этих подходов позволит квалифицированным преподавателям реально и главным образом учить молодежь тому, как она должна думать, рефлексировать, а не тому, что или о чем она должна думать. Низкий уровень качества подготовки вузовских специалистов обусловливается главным образом недостаточной, ранее отмечаемой, для обучения в вузе довузовской подготовки, зауженным горизонтом общей культуры студентов, не очень замотивированных на ответственное обучение и не соответствующих своему социальному статусу ${ }^{16}$ - статусу студента (лат. studens - усердно работающий, занимающийся).

События, разворачивающиеся на полях индустрии знаний, всеобщего образовательного процесса, переносят нас в старую Обломовку И.А. Гончарова, персонаж которого, плененный ленью и апатией, полагал, что «большая часть капитала знаний ни на что не понадобится в жизни».

Но если Илью Ильича Обломова иногда одолевал позыв познакомиться с каким-либо произведением и быть совершенно довольным, то известному персонажу - Митрофану - в пьесе Д.И. Фонвизина «Недоросль» никогда в голову не приходила мысль о необходимости изучения, например, географии, дающей «знания того, куда мы едем», будучи уверенным в том, что «без этих знаний обойдемся ${ }^{17}$, «кучер довезет».

Описанная история родственных в определенном смысле человеческих душ России крепостной, история, по сути, трагическая,

\footnotetext{
15 «Принято думать, что между крайними точками зрения лежит истина. Никоим образом: между ними лежит проблема» - Иоганн В.Гете.

${ }^{16}$ Гильотина Юма: «Невозможно вывести то, что должно быть, из того, что есть » - Дэвид Юм.

17 «Как много вещей на свете, которые мне не нужны» - Сократ.
} 
повторяется в переживающей все мыслимые кризисы (особенно нравственный) современной России не в виде фарса ${ }^{18}$, легкой комедии, а в виде трагикомедии - синтеза плачевного, трагического и смешного. Если студент на первое место по значимости в иерархии ресурсов, источников своих знаний ставит СМИ и Интернет (в которых, конечно же, можно найти и «жемчужное зерно» (Крылов), но которые никогда не станут эквивалентном подлинных классических источников познания «из первых рук», обсуждаемых в студенческой аудитории), этих современных «кучеров», то процесс получения знаний будет просто сводиться к обретению навыков ${ }^{19}$ работы с Интернетом, к избыточной загрузке студентов информацией, не пополняющей их знания и далеко не осмысленной, но предназначенной исключительно для отчета по самостоятельной работе перед преподавателем. Более высокая компетентность и оперативность интернет-ресурсов, с одной стороны, облегчает работу преподавателя (в том числе и в части углубления их знаний, почерпнутых из студенческих докладов и рефератов), а с другой стороны, усложняет, имея в виду объективно обусловленный резкий разворот в их работе, направленной по вектору развития мыслительной деятельности у студентов.

И последнее. Процесс социализации личности, как известно, это процесс становления личности, усвоения знаний, ценностей и норм, присущих данному обществу на различных этапах (периодах) его развития. Современная молодежь живет и учится в условиях (или под влиянием) разновекторных факторов - трансформации ценностнонормативной системы, новой социальной дифференциации в обществе, изменения шкалы престижности профессий, снижения уровня жизни, роста безработицы, углубления неравенства, в том числе и в среде образования.

\section{Заключение}

Аксиоматичным и незыблемым является то, что знакомство и усвоение литературного наследия отечественных и зарубежных классиков, мастеров русской классической прозы и поэзии, мыслящих категориями общечеловеческими ${ }^{20}$, раскрывающих диалектику нравственно-философской и социальной мысли, отражаемой

\footnotetext{
18 «История повторяется дважды: первый раз в виде трагедии, второй - в виде фарса» -- Г. Гегель.

19 «Образование - это всего лишь ключ, отпирающий двери библиотек» - А. Моруа.

${ }^{20}$ «И самого себя по шее гладя, - уговаривал себя Есенин, - я говорю - настал наш срок: давай, Сергей, за Маркса тихо сядем, чтоб разгадать премудрость скучных строк».
} 
изысканной терминологией и стилем, а также знание философии, классической политической экономии, социологии, психологии, демографии, политологии и других дисциплин, изучаемых в образовательных учреждениях, сулит молодым людям репутацию передового, продвинутого человека.

Высокая культура человека, широкая эрудиция защитят его от опасности быть «срезанным» шукшинским персонажем (работником пилорамы), кругозор которого оказался выше горизонта знаний кандидатов наук, не сведущих ни в вопросах философии (что первично, а что вторично), ни в вопросах мироздания и т.д. Поскольку «поток информации сейчас распространяется везде равномерно», - говорит главный персонаж рассказа В. Шукшина «Срезал» [9, с. 10-12], постольку образование главным образом есть не что иное как самообразование, самосочинение (Достоевский), покоящееся, как уже отмечалось, на трех «сваях» (Даль) - желании, терпении и усердии.

\section{ИСТОчнИКИ:}

1. Даль В.И. Толковый словарь живого великорусского языка. В 4-х т. Т. 2. - СПб: Диамант, 1996. -784 c.

2. Доклад о человеческом развитии 2014. Обеспечение устойчивого прогресса человечества: уменьшение уязвимости и формирование жизнестойкости. - М.: Весь мир, 2014. -236 с.

3. Доклад о человеческом развитии в Российской Федерации за 2014 год. - М.: Аналитический центр при Правительстве Российской Федерации, 2014. - 204 с.

4. Доклад о человеческом развитии 2013. Возвышение Юга: человеческий прогресс в многообразном мире. - М.: Весь мир, 2013. - 204 с.

5. Косьмина Е.А. Векторы и интенсивность воздействия доминирующих форм совокупного капитала на народное благосостояние. Теория. Методология. Оценка. - Москва: Экономика, 2009. - 607 с.

6. К. Маркс и Ф. Энгельс. Сочинения: В 50 т. Т. 46. Ч. ІІ. К. Маркс: Экономические рукописи 1857-1859 годов. - 2-е изд. - М.: Издательство политической литературы, 1969. $618 \mathrm{c}$.

7. Маркс К. Тезисы о Фейербахе // К. Маркс и Ф. Энгельс. Сочинения: В 50 т. Т. 42. - 2-е изд. - М.: Издательство политической литературы. - С. 261-263.

8. Смит А. Исследование о природе и причинах богатства народов. - М.: Соцэкгиз, 1962. $684 \mathrm{c}$.

9. Шукшин В. Срезал // Собрание сочинений в пяти томах. Т. 2. - С. 7-14.

10. Энгельс Ф. Людвиг Фейербах и конец классической немецкой философии // К. Маркс и Ф. Энгельс. Сочинения: В 50 т. Т. 21. - 2-е изд. - М.: Издательство политической литературы, 1961. - 746 с. - С. 269-317. 
11. PISA [Electronic resource] // OECD. - Mode of access: http://www.pisa.oecd.org/

12. Послание Президента Федеральному Собранию [Электронный ресурс] // Сайт

Президента России. - 2015. - 3 декабря. - Режим доступа:

http://kremlin.ru/events/president/news/50864

Anatoly D. Kosmin, Doctor of Science, Economics; Professor, Omsk State Technical University

Vladimir V. Kuznetsov, Doctor of Science, Economics; Omsk State Technical University; Junior Researcher, National Research Tomsk Polytechnic University

Olga P. Kuznetsova, Doctor of Science, Economics; Professor, Omsk State Technical University

Olga V. Galtseva, Candidate of Science, Engineering, National Research Tomsk Polytechnic University

\section{Issues of increasing effectiveness of investment to education}

\section{ABSTRACT}

The range and effectiveness of investments to education, scientific research and development are determined. The need in change in the social status of the educational system and in the increased range of funding as the essential condition for the increased quality of professional training is proven.

KEYWORDS: formal and real education, quality of education, effectiveness of investments to education and scientific research, priorities, motivation 